\title{
A Newly Isolated Thermostable Lipase from Bacillus sp.
}

\section{Fairolniza Mohd Shariff ${ }^{1}$, Raja Noor Zaliha Raja Abd. Rahman ${ }^{1} *$, Mahiran Basri ${ }^{2}$ and Abu Bakar Salleh ${ }^{1}$}

1 Enzyme and Microbial Technology Research, Faculty of Biotechnology and Biomolecular

Sciences, University Putra Malaysia, 43400 UPM Serdang, Selangor, Malaysia;

E-Mails: ferrol2506@gmail.com (F.M.S.); abubakar@biotech.upm.edu.my (A.B.S.)

2 Enzyme and Microbial Technology Research, Faculty of Science, University Putra Malaysia, 43400 UPM Serdang, Selangor, Malaysia; E-Mail: mahiran@science.upm.edu.my

* Author to whom correspondence should be addressed; E-Mail: rnzaliha@ biotech.upm.edu.my; Tel.: +603-8946-7592; Fax: +603-8947-7593.

Received: 31 January 2011; in revised form: 25 March 2011 / Accepted: 12 April 2011 /

Published: 4 May 2011

Abstract: A thermophilic lipolytic bacterium identified as Bacillus sp. L2 via 16S rDNA was previously isolated from a hot spring in Perak, Malaysia. Bacillus sp. L2 was confirmed to be in Group 5 of bacterial classification, a phylogenically and phenotypically coherent group of thermophilic bacilli displaying very high similarity among their $16 \mathrm{~S}$ rRNA sequences (98.5-99.2\%). Polymerase chain reaction (PCR) cloning of L2 lipase gene was conducted by using five different primers. Sequence analysis of the L2 lipase gene revealed an open reading frame (ORF) of $1251 \mathrm{bp}$ that codes for 417 amino acids. The signal peptides consist of 28 amino acids. The mature protein is made of 388 amino acid residues. Recombinant lipase was successfully overexpressed with a 178 -fold increase in activity compared to crude native L2 lipase. The recombinant L2 lipase (43.2 kDa) was purified to homogeneity in a single chromatography step. The purified lipase was found to be reactive at a temperature range of $55-80{ }^{\circ} \mathrm{C}$ and at a $\mathrm{pH}$ of $6-10$. The L2 lipase had a melting temperature (Tm) of $59.04{ }^{\circ} \mathrm{C}$ when analyzed by circular dichroism (CD) spectroscopy studies. The optimum activity was found to be at $70{ }^{\circ} \mathrm{C}$ and $\mathrm{pH} 9$. Lipase L2 was strongly inhibited by ethylenediaminetetraacetic acid (EDTA) (100\%), whereas phenylmethylsulfonyl fluoride (PMSF), pepstatin-A, 2-mercaptoethanol and dithiothreitol (DTT) inhibited the enzyme by over $40 \%$. The CD spectra of secondary structure analysis showed that the L2 lipase structure contained $38.6 \% \quad \alpha$-helices, $2.2 \% \quad \beta$-strands, $23.6 \%$ turns and $35.6 \%$ random conformations. 
Keywords: Bacillus sp. strain L2; thermostable lipase; cloning; sequencing; molecular expression; characterization

\section{Introduction}

Lipolytic enzymes are currently attracting significant attention because of their biotechnological potential. Most of the lipases used in industry are microbial enzymes, of both fungal and bacterial origin [1]. Lipases are an important group of enzymes both physiologically and commercially as the use of lipases for a variety of biotechnological applications is rapidly and steadily increasing [2]. In general, lipases have promising applications in organic chemical processing, detergent formulation, synthesis of biosurfactants, the agrochemical industry, paper manufacture, nutrition, cosmetics and pharmaceutical processing [3].

Thermostability is a desirable characteristic because it may allow the enzyme to endure conditions in industrial processes that use relatively high temperatures and/or organic solvents. Furthermore, enzymes from thermophilic bacteria have been found to be generally more resistant to denaturation than their mesophilic counterparts [4]. In this paper, identification of an industrially important lipase producer was conducted to determine its phylogenetic position in systematic microbiology. We also described a method for the rapid cloning of the lipase gene from thermophilic Bacillus sp. L2 using a set of consensus primers and Polymerase chain reaction (PCR) techniques, followed by expression and purification of the recombinant L2 lipase gene, and some properties of the purified enzyme including the circular dichroism (CD) spectroscopy studies.

\section{Results and Discussion}

\subsection{Bacterial Identification}

Bacillus sp. L2 is an aerobic, non-motile Gram positive rod able to grow at a temperature range between $40-80{ }^{\circ} \mathrm{C}$ with an optimum growth at $70{ }^{\circ} \mathrm{C}$ and optimum $\mathrm{pH}$ of 7 . The $16 \mathrm{~S} \mathrm{rDNA}$ nucleotide sequence of this strain has been deposited into GenBank data library and assigned the accession number AY 964643. BLAST results showed that Bacillus sp. L2 has highest homology with G. thermoglucosidiasus (AY 608988) with a significant value of 99\% homology. From the phylogenetic tree and the $\mathrm{G}+\mathrm{C}$ contents of $16 \mathrm{~S}$ rRNA sequences, Bacillus sp. L2 was confirmed to be in Group 5 of bacterial classification (Figure 1). Group 5 is a phylogenically and phenotypically coherent group of thermophilic bacilli displaying very high similarity among their 16S rRNA sequences (98.5-99.2\%) [5]. Bacillus sp. L2 was found to cluster closely with two other strains, G. caldoxylosilyticus (AJ 564613) and Bacillus sp. Ak1 (L 29507). The results from BLAST by NCBI also showed that Bacillus sp. L2 has 98\% homology with these two strains, and also 99\% homology with G. thermoglucosidiasus (AY 608988). However, from the phylogenetic tree, it was found that this Bacillus sp. L2 did not cluster closely with G. thermoglucosidiasus (AY 608988). So far, there are no reports on lipase production from either the G. thermoglucosidiasus or the G. caldoxylosilyticus species. 
Figure 1. Rooted phylogenetic tree showing the relationship of isolate Bacillus sp. L2 to other Bacillus and Geobacillus species with their accession numbers.

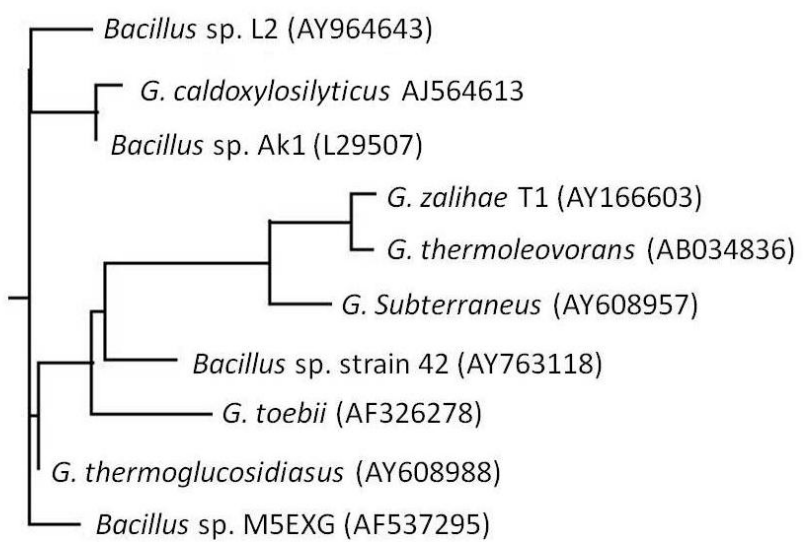

\subsection{Isolation and PCR Cloning of the Thermostable L2 Lipase Gene}

A fragment of lipase gene $300 \mathrm{bp}$ in size was obtained using a pair of highly degenerate primers (Lip F2 and Lip R2). This lipase gene fragment showed the highest homology with the B. stearothermophilus P1 lipase gene at 99\% homology. Primer P1F1 was designed based on the first 21 nucleotides of the ORF of $B$. stearothermophilus P1 lipase gene sequence, whereas primer P1R1 was from the last 21 nucleotides of the same sequence. The combination of these new primers (P1F1 and P1R2) was not able to amplify any PCR product. However, the combination of primer P1R1 with primer Lip F2 was successful and an 800-bp gene fragment was obtained through PCR amplification. The purified PCR product was sent for sequencing and based on the sequence, this lipase gene showed high similarities with most of the Bacillus thermostable lipase genes, especially Geobacillus sp. T1 (AY 260764) (92\%).

Based on the high similarities with Geobacillus sp. T1, a new forward primer, F, was designed. The combination of primer F and Lip R2 successfully amplified a PCR product with a size of $\sim 700 \mathrm{bp}$. The purified DNA was sent for sequencing and the sequence obtained was later used to design another forward primer which started at the mature lipase gene sequence, which was later used to amplify a complete mature lipase gene ( 1200 bp) when combined with primer P1R1. The 1200-bp PCR product obtained was eluted from the gel and then ligated into a U-overhang vector, pQE-30. Positive transformants showed a cleared zone around the colonies on a tributyrin-LB plate with associated antibiotic agar after overnight incubation at $37^{\circ} \mathrm{C}$. The positive clones were streaked onto triolein-LB agar to screen for true lipase producers and were incubated overnight at $37{ }^{\circ} \mathrm{C}$. The recombinant clones formed an intense blue color on the triolein-LB agar plate (data not shown).

\subsection{Sequence Analysis of the Thermostable L2 Lipase}

The plasmid harboring the L2 gene was sequenced and shown to contain a $1.2 \mathrm{~kb}$ sequence coding for lipase. The complete sequence of the ORF of the L2 lipase gene was submitted to GenBank and was assigned accession number AY855077. The amino acid composition within the ORF was determined by the ProtParam Tool of the ExPASy Molecular Biology server [6]. The molecular mass and the isoelectric point $(\mathrm{pI})$ were predicted to be $46.31 \mathrm{kDa}$ and 6.36 , respectively. The putative signal 
peptide cleavage site of Bacillus sp. L2 lipase was found to be located between Ala-28 and Ala-29, based on the rules for signal peptide sequences and based on predictions from the SignalP V2.0 Web server [7]. In all lipases, a catalytic triad of Ser, His and Asp (or Glu in a few lipases) is present [8]. Thus, the predicted catalytic triad of Bacillus sp. L2 lipase should be formed by His-42, Ser-14 and Asp-345 according to comparisons with the His, Ser and Asp catalytic triad of other Bacillus lipases (Figure 2).

Figure 2. Homology lineup of lipases from several bacteria species.

\begin{tabular}{|c|c|}
\hline AY_260764____ & -------1 \\
\hline $\mathrm{AY}-855077$ & ----------- \\
\hline $\mathrm{AF}_{-}^{-} 134840_{-}^{-}$ & 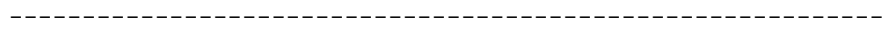 \\
\hline $\mathrm{AF}_{-}^{-} 237623_{-}^{-}$ & 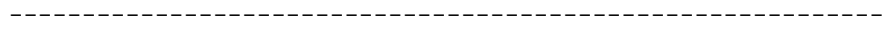 \\
\hline JW_0068_ & 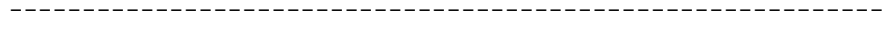 \\
\hline NP_978931_ & 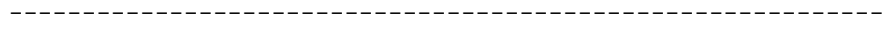 \\
\hline NP_781602_ & 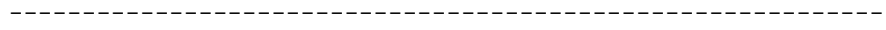 \\
\hline YP_042090_ & MMKSQNKYSIRKFSVGASS ILIATLLFLSGGQAQAAEKQVNMGNSQEDTVTAQS IGDQQT \\
\hline YP_111747_ & - \\
\hline $\mathrm{NP}_{-} 744233_{-}$ & 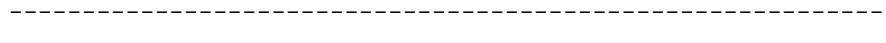 \\
\hline AY_260764___ra & 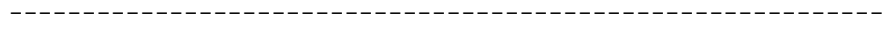 \\
\hline AY_ $855077^{-}$ & 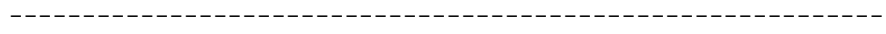 \\
\hline AF_134840_- & 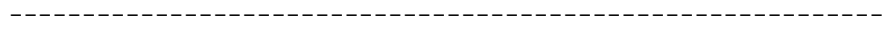 \\
\hline AF_237623_ & - - - - \\
\hline JW_0068_- & 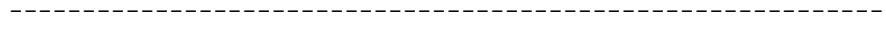 \\
\hline NP_978931_- & 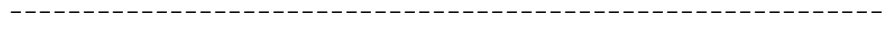 \\
\hline NP_781602_- & 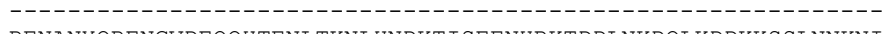 \\
\hline YP_042090_- & RENANYQRENGVDEQQHTENLTKNLHNDKTISEENHRKTDDLNKDQLKDDKKSSLNNKNI \\
\hline YP_111747_- & 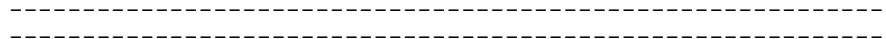 \\
\hline${ }^{\mathrm{NP}}-144233-$ & 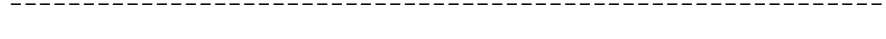 \\
\hline AY_260764_ & ------------------------------------------------------------- MKCCRI \\
\hline AY_855077_ & - \\
\hline AF_134840_ & 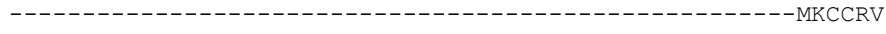 \\
\hline AF_237623_ & $----------------------------------------------------M M K G C R V$ \\
\hline JW_0068_ & 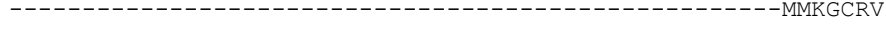 \\
\hline NP_978931_ & 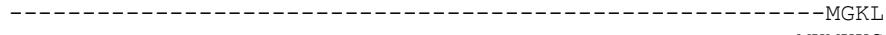 \\
\hline $\mathrm{NP}_{-} 781602$ & 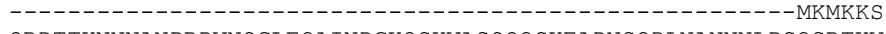 \\
\hline YP_042090_- & QRDTTKNNNANPRDVNQGLEQAINDGKQSKVASQQQSKEADNSQDLNANNNLPSQSRTKV \\
\hline YP_111747_ & - \\
\hline NP_744233_ & - - - \\
\hline AY_260764 & 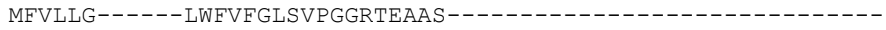 \\
\hline $\mathrm{AY}-855077$ & MFVLLG------LWFVFGLSVPGGRTEAAS-------------------------- \\
\hline AF_134840_ & 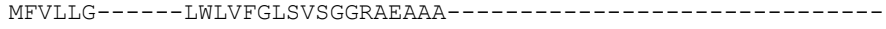 \\
\hline $\mathrm{AF}^{-} 237623^{-}$ & 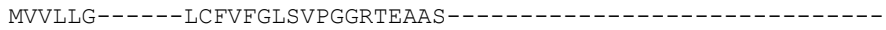 \\
\hline JW_0068 & 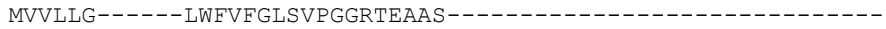 \\
\hline NP_ $9789 \overline{3} 1$ & FLKIC------FFALVAVCSLVAKITYAEE --------------------------- \\
\hline NP_781602_ & LTKITGITLLTFF ISLTNFS ITARAAEQKVRTPQSIKEEINNSMKSGKAVKEDDINELAP \\
\hline YP_042090_ & SPSLNKSDQTSQREIVNETEIEKVQPQQKNQANDKITDHNFNNEQEVKPQKDEKTLSVSD \\
\hline YP_111747_ & 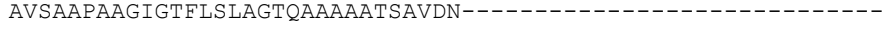 \\
\hline $\mathrm{NP}_{-} 744233_{-}$ & 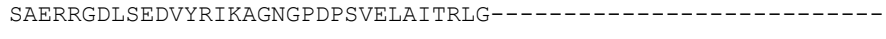 \\
\hline AY_260764 & 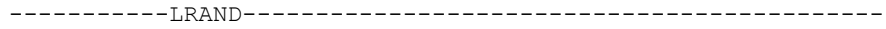 \\
\hline AY_855077 & ----------- LRAND -------------------------------------------- \\
\hline $\mathrm{AF}^{-} 134840$ & 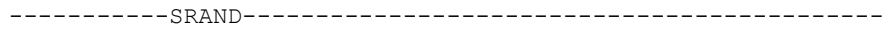 \\
\hline AF_237623 & ----------- LRAND ------------------------------------------------ \\
\hline JW_0068_ & ----------- PRAND -------------------------------------------- \\
\hline NP_978931_ & 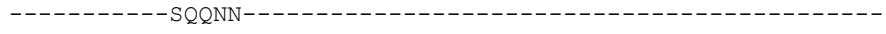 \\
\hline NP_ 781602 & LEFPEINTRS ITKDNN \\
\hline YP_042090_ & LKNNQKSPVEPTKDNDKKNGLNLLKSSAVATLPNKGTKELTAKAKGDQTNKVAKQGQYKN \\
\hline YP_111747_ & 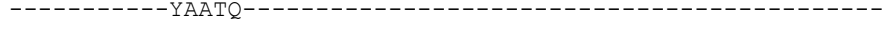 \\
\hline NP_744233_ & 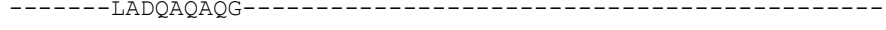 \\
\hline AY_260764 & -APIVLLHGFTGWGREE--MFGFKYWGGVRGDIEQWLNDNGYRTFTLAVGPLSSNWDRAC \\
\hline AY_855077_- & -APIVLLHGFTGWGREE--MFGFKYWGGVRGDIEQWLNDNGYRTYTLAVGPLSSNWDRAC \\
\hline AF_134840 & -APIVLLHGFTGWGREE--MFGFKYWGGVRGDIEQWLNDNGYRTYTLAVGPLSSNWDRAC \\
\hline AF_237623_ & -APIVLLHGFTGWGREE--MFGFKYWGGVRGDIEQWLNDNGYRTYTLAVGPLSSNWDRAC \\
\hline JW_0068_ & -APIVLLHGFTGWGREE--MLGFKYWGGVRGDIEQWLNDNGYRTYTLAVGPLSSNWDRAC \\
\hline NP_978931_ & -YPIILVNGFAGWGREE--MLGVKYWGGVH-DIQEDLKRNGYTVHTAAVGPVSSNWDRAC \\
\hline NP_781602_ & -YPI I LVHGFMGYGRDE--LLGYKYWGGVV-DLQEKLNNSGHKAYTATVGPVSSNWDRAC \\
\hline YP_042090_- & QDP IVLVHGFNGFTDDINPSVLAHYWGGNKMNIRQDLEENGYKAYEAS ISAFGSNYDRAV \\
\hline
\end{tabular}


Figure 2. Cont.

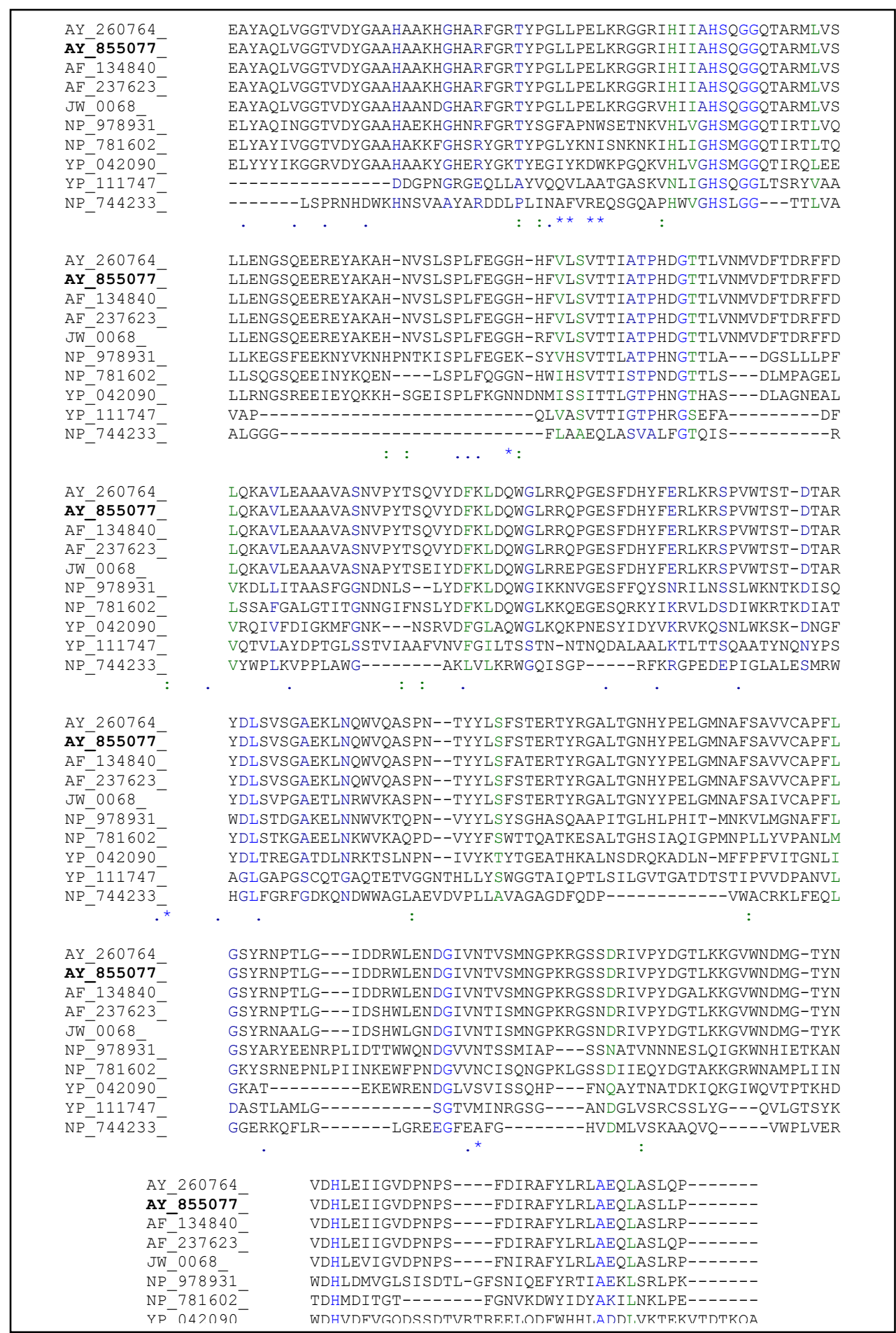

Note: All the lipases were labeled based on their accession numbers submitted to the GenBank. Geobacillus sp. T1 lipase (AY 260764); Bacillus sp. L2 lipase (AY 855077); B. thermoleoverans ID-1 lipase (AF 134840); B. stearothermophilus P1 lipase (AF 237623); B. stearothermophilus LI lipase (JW 0068); B. cereus ATCC 10987 lipase (NP 978931); Clostridium tetani lipase (NP 781602); Staphylococcus aureus subsp. aureus MRSA252 lipase (YP 042090); Burkholderia pseudomallei K96243 lipase (YP 111747) and Pseudomonas putida lipase (NP 744233). 


\subsection{Overexpression of the L2 Lipase Gene}

High-level expression using the pQE-30 vector is based on the T5 promoter transcription-translation system. The expression of E. coli M15[pREP4] harboring recombinant plasmids was rapidly induced by addition of $1.0 \mathrm{mM}$ isopropyl- $\beta$-D-thio-galactoside (IPTG) for two hours of induction time (Figure 3a). These expression levels were 172-fold higher than those produced by the native Bacillus sp. L2 and the transformed E. coli in the absence of IPTG. A higher concentration of IPTG was not used in this experiment because it was assumed that higher concentration of IPTG would result in significant retardation of cell growth, resulting in a lower protein yield [9]. The same IPTG concentration was used by Sinchaikul et al. (2001) with a post-induction time of two hours for expression of the thermostable lipase P1 using vector pQE-60 and E. coli M15[pREP4] as host cells [10]. In addition, Leow et al. (2004) also reported that $1 \mathrm{mM}$ of IPTG was used for expression of thermostable lipase T1 using several vectors, including pET22b(+), pRSET, and pGEX-4T1 [11]. However, Nthangeni et al. (2001) reported that only $0.5 \mathrm{mM}$ of IPTG was used to induce the expression of lipase from B. licheniformis using pET20b(+) and E. coli JM109 (DE3) as expression vector and host, respectively [12].

Figure 3. (a) SDS-PAGE gel shows IPTG induction of the recombinant lipase; M, Standard protein markers; Lane 1, No added IPTG; Lane 2, 1 mM IPTG; (b) SDS-PAGE; M, Standard protein markers; Lane 1-3, Purified fractions; Lane 4, Crude protein; and (c) Native-PAGE gels of L2 His-tagged recombinant L2 purified through Ni-Sepharose 6 Fast Flow affinity chromatography; M, Standard protein markers; Lane 1-3, Purified fractions.

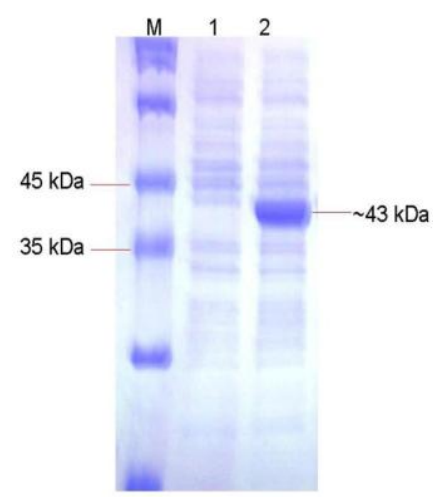

(a)

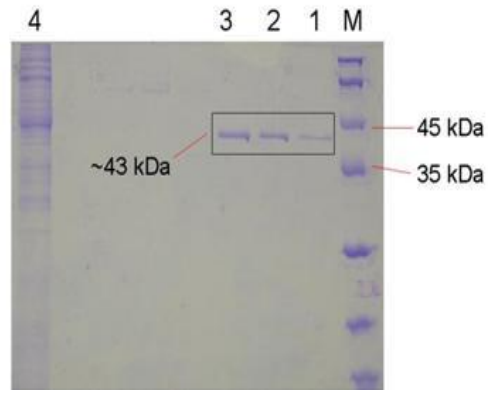

(b)

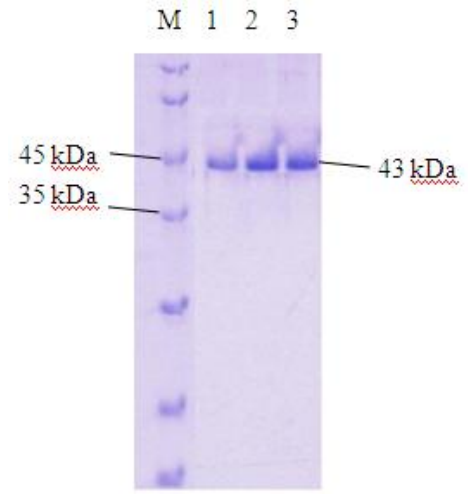

(c) 


\subsection{Purification of Recombinant L2 Lipase}

The recombinant His-tagged L2 lipase was successfully purified to homogeneity by the single-step affinity chromatography method. With this purification strategy, a $76.1 \%$ recovery was achieved with a purification of 1.6 fold and a specific activity of $75.8 \mathrm{U} / \mathrm{mg}$. The yield was found to be higher than the yields of either His-tagged Staphylococcus xylosus lipase (66\% of recovery) or its mutant (71\% of recovery) [13]. Although the purification level for THL027 lipase was high (2.6-fold), its recovery was found to be only $27 \%$ with a specific activity of $4.5 \mathrm{U} / \mathrm{mg}$, analyzed after using a single step of Sephadex G-100 gel filtration prior to ultrafiltration through a $10 \mathrm{kDa}$ cut-off membrane [14]. The results of SDS-PAGE analysis of the Ni-Sepharose affinity chromatography-purified recombinant L2 lipase are shown in Figure $3 \mathrm{~b}$. The oligomeric state of the purified recombinant L2 lipase was predicted to be monomer as L2 lipase was found to be migrated as a single band on both SDS-PAGE and Native-PAGE gels with a relative molecular mass of approximately $43 \mathrm{kDa}$ in Figure $3 \mathrm{c}$.

\subsection{Effect of pH on Lipase Activity and Stability}

The effect of $\mathrm{pH}$ on enzyme activity was examined in the $\mathrm{pH}$ range of 4.0 to 12.0 (Figure $4 \mathrm{a}$ ). Maximal lipolytic activity towards olive oil was observed at $\mathrm{pH}$ 9.0. At $\mathrm{pH}$ 10, L2 lipase remained at $50 \%$ of its activity and the activity started to decrease tremendously when the lipase was assayed at higher $\mathrm{pH}$ levels. L2 lipase also seemed to have low activity at acidic to neutral $\mathrm{pH}$ as it only had $20 \%$ of its activity at $\mathrm{pH} 5$ to $\mathrm{pH}$ 7. The high enzyme activity at $\mathrm{pH} 9$ to 10 may be a result of the Ala for the first Gly-residue in the consensus sequence Gly-X-Ser-X-Gly [15]. The pH-stability of L2 showed that it was fairly stable ( $>40 \%$ of relative activity) at pHs ranging from 8.0 to 10 after being treated for $30 \mathrm{~min}$ at $70{ }^{\circ} \mathrm{C}$ in both Tris- $\mathrm{HCl}$ and Glycine-NaOH buffers (Figure 4b). L2 lipase was most stable at $\mathrm{pH} 9.0$.

Figure 4. (a) $\mathrm{pH}$ profile of purified recombinant L2 lipase; (b) $\mathrm{pH}$ stability of purified recombinant L2 lipase. Symbols used are: (n) Acetate buffer; $(\Delta)$ Potassium phosphate buffer; ( $\bullet$ Tris-HCl buffer; ( $\square$ ) Glycine-NaOH buffer; $(\bullet) \mathrm{Na}_{2} \mathrm{HPO}_{4} / \mathrm{NaOH}$ buffer.

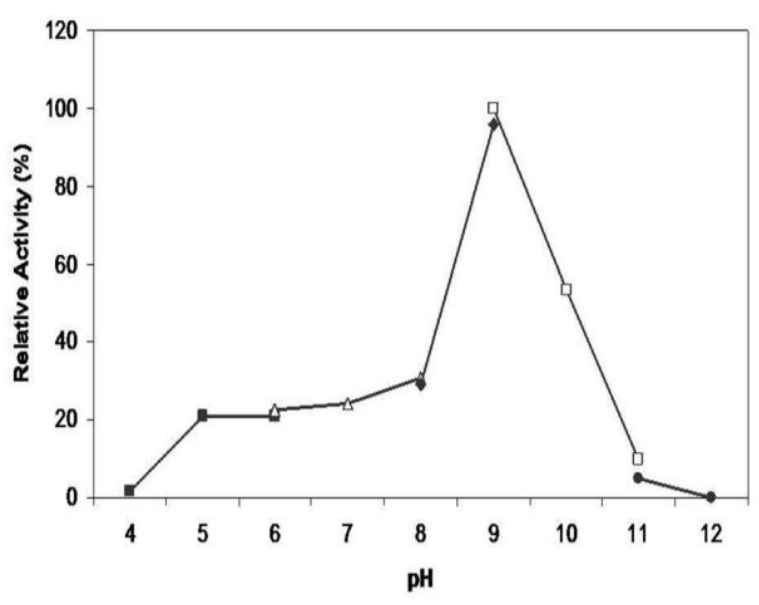

(a)

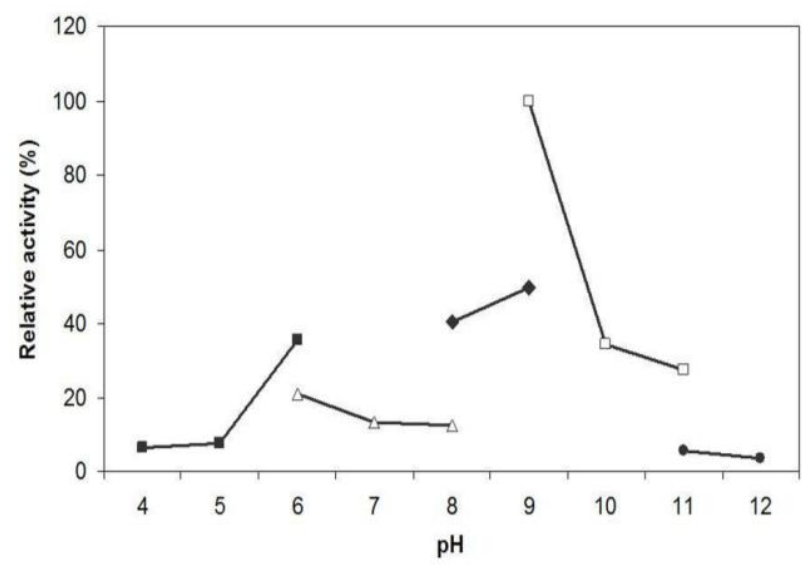

(b) 


\subsection{Effect of Temperature on Activity and Thermostability Profile}

L2 lipase was most active in the temperature range of 55 to $75{ }^{\circ} \mathrm{C}$, with more than $75 \%$ of its lipolytic activity remaining, and exhibited its maximal activity at $70{ }^{\circ} \mathrm{C}$ (Figure 5a). These characteristics indicated that L2 lipase is a thermostable lipase. Studies by Dharmsthiti and Luchai (1999) on THL027 lipase showed that it was highly active at $70{ }^{\circ} \mathrm{C}$ even though the lipase molecular mass was relatively higher $(69 \mathrm{kDa})$ than that of the three thermostable lipases mentioned earlier [14]. Lower optimum temperatures were found from other thermostable lipases such as that produced by Bacillus strain J33 [16], Bacillus sp. RSJ-1 [17] and Bacillus A30-1 [18], where their optimum temperatures were around 50 to $60^{\circ} \mathrm{C}$.

The purified L2 lipase was stable at $60{ }^{\circ} \mathrm{C}$ with a half-life $\left(\mathrm{t}_{1 / 2}\right)$ of $2 \mathrm{~h}$ (Figure $5 \mathrm{~b}$ ), similar to the characteristics of BTID-B lipase that were reported previously [19]. At the same temperature, L2 lipase retained more than $40 \%$ of its original activity for $3 \mathrm{~h}$ and $45 \mathrm{~min}$. The thermostability of L2 lipase was higher than that of the previously reported lipase Bacillus stearothermophilus L1 [20] which was stable at $60{ }^{\circ} \mathrm{C}$ for $30 \mathrm{~min}$. The relatively high stability of this enzyme at high temperatures fits requirements for industrial processes.

Figure 5. (a) Temperature profile of purified recombinant L2 lipase; and (b) Thermostability profile of purified recombinant L2 lipase. The L2 lipase was incubated at different temperatures in Glycine- $\mathrm{NaOH}$ buffer $\mathrm{pH} 9$ and the residual activity was assayed at $70{ }^{\circ} \mathrm{C}$ (optimum temperature). The symbols used are: (口) $80{ }^{\circ} \mathrm{C}$; $(\Delta) 70{ }^{\circ} \mathrm{C}$; (०) $65^{\circ} \mathrm{C}$; and $(\diamond) 60^{\circ} \mathrm{C}$.

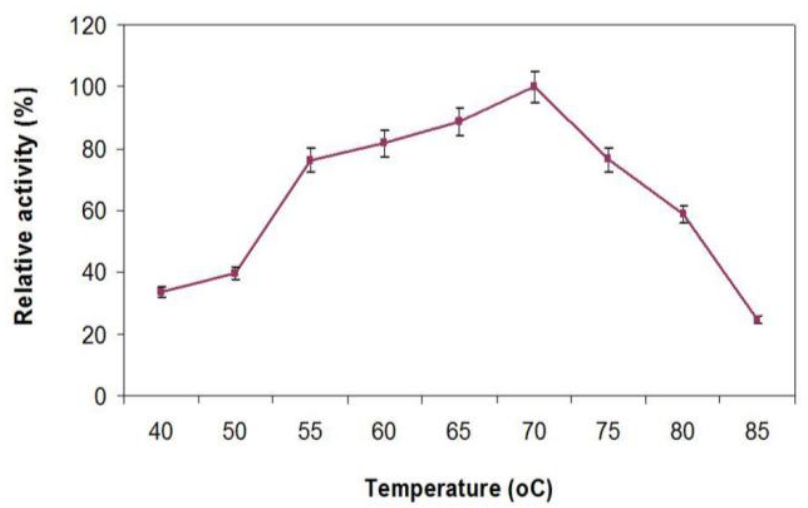

(a)

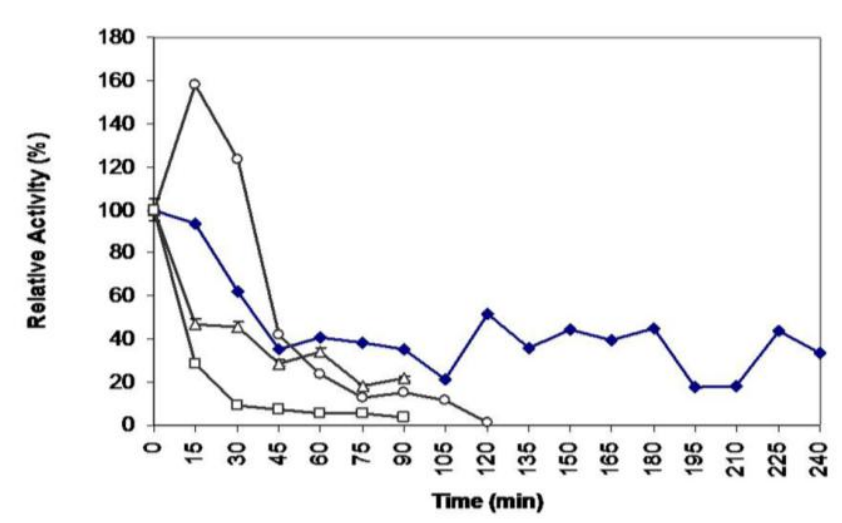

(b)

\subsection{Denatured Protein Analysis of L2 Lipase}

Figure 6 shows the CD spectra of the L2 lipase measured at various temperatures. From this study, it was found that the melting point, $\mathrm{T}_{\mathrm{m}}$ for L2 lipase was $59.04{ }^{\circ} \mathrm{C}$. In agreement, the half-life for L2 lipase was around $120 \mathrm{~min}$ at $60{ }^{\circ} \mathrm{C}$ as the treatment temperature is slightly below its $\mathrm{T}_{\mathrm{m}}$. 
Figure 6. The CD spectra of L2 lipase at $220 \mathrm{~nm}$ denatured protein analysis. The fitting lines and thermal bar were indicated in blue and red, respectively.

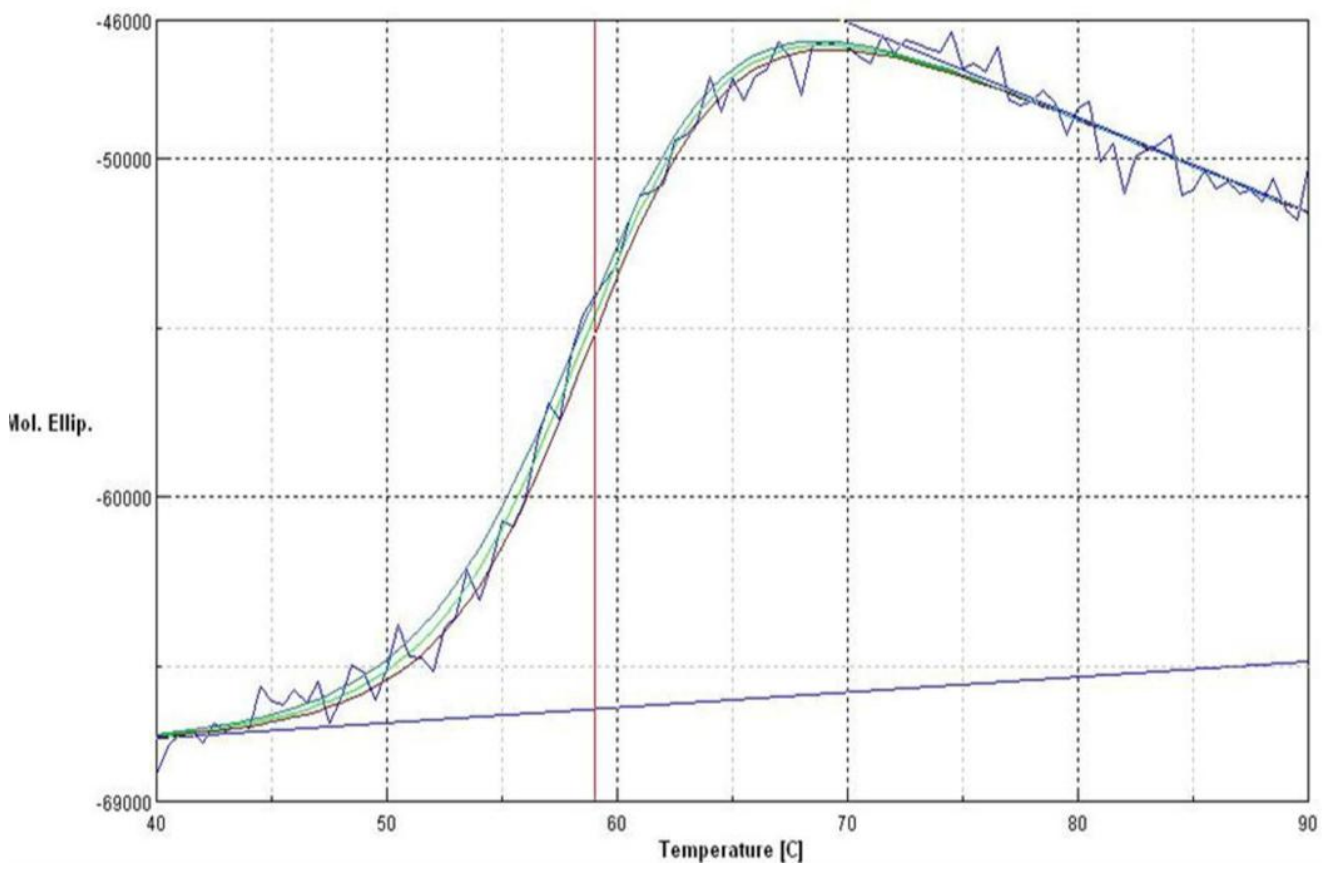

\subsection{Effect of Metal Ions on Lipase Activity}

Many enzymes contain metal ions to maintain a stable and active structure, where the metal ions are bound strongly to specific binding sites on the surface of the molecules. Stabilization of enzymes by metal ions at high temperatures occurs by metal ion complexing, a process with a favorable entropy factor [21]. The presence of metal ions is believed to have a significant effect on the rigidity and hence the stability of enzymes. In the present study, it was found that the presence of $\mathrm{Ca}^{2+}$ ions $(1 \mathrm{mM}$ and $10 \mathrm{mM}$ ) greatly increased the L2 lipase activity by approximately 100-200\% (Figure 7). The L2 lipase activity was also promoted in the presence of $1 \mathrm{mM} \mathrm{Mn}^{2+}, \mathrm{K}^{+}$and $\mathrm{Na}^{+}$by $100-155 \%$ of its relative activity. The addition of $10 \mathrm{mM}$ of metal ions such as $\mathrm{Zn}^{2+}, \mathrm{Mn}^{2+}, \mathrm{Mg}^{2+}, \mathrm{Fe}^{2+}$ and $\mathrm{Cu}^{2+}$ decreased the activity by more than $60 \%$.

\subsection{Influence of Various Effectors on L2 Lipase Activity}

Figure 8 showed the relative activity of L2 lipase after being treated for $30 \mathrm{~min}$ at $65{ }^{\circ} \mathrm{C}$ with $1 \%$ and $5 \%$ of various effectors. EDTA treatments (both $1 \%$ and $5 \%$ ) were found to strongly inhibit L2 lipase, especially at $5 \mathrm{mM}$ EDTA, which caused a complete block of activity (0\%). This result indicates that the enzyme is a metalloenzyme. Similar inhibition was also reported on the lipases BTID-A and BTID-B [18]. Treatments of L2 lipase with PMSF and pepstatin A also showed strong inhibitory effects (more than 60\% inhibition), indicating that the catalytic triad of L2 lipase consists of Ser-His-Asp. DTT and 2-mercaptoethanol showed moderate inhibitory effects to the activity of L2 lipase at a concentration of $1 \mathrm{mM}$, but significantly high levels of inhibition when a $5 \mathrm{mM}$ concentration was used. 
Figure 7. Effect of metal ion on purified recombinant L2 lipase. L2 lipase was preincubated at $65^{\circ} \mathrm{C}$ for $30 \mathrm{~min}$ with different metal ions at $1 \mathrm{mM}(\square)$ and $10 \mathrm{mM}(\square)$ prior to lipase assay. The remaining activity was determined at $70{ }^{\circ} \mathrm{C}$ using olive oil emulsion (1:1, v/v in Glycine- $\mathrm{NaOH}$ buffer $\mathrm{pH} 9)$ and expressed as a percentage of the activity without the metal chlorides.

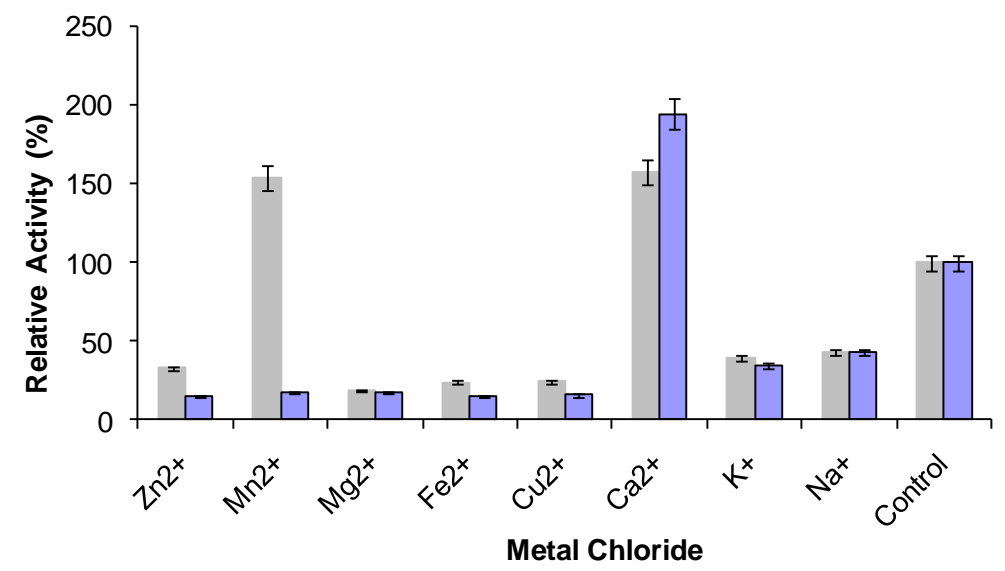

Figure 8. Influence of effectors on purified recombinant L2 lipase activity. The L2 lipase was incubated with $1 \mathrm{~mm}$ and $5 \mathrm{~mm}$ of effectors (except Pepstatin A) at $65{ }^{\circ} \mathrm{C}$ for $30 \mathrm{~min}$ prior to lipase assay at standard conditions.

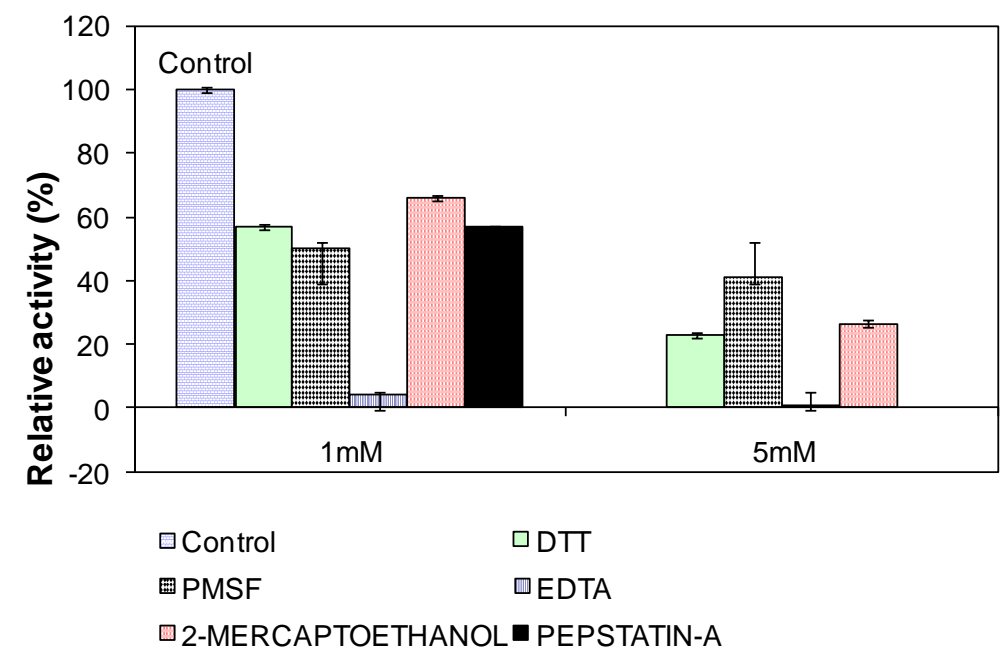

\subsection{Secondary Structure Prediction of L2 Lipase by Circular Dichroism (CD) Spectral Analysis}

One of the most successful applications of $\mathrm{CD}$ in characterizing a protein depends upon the remarkable sensitivity of the far-UV to the backbone conformation of proteins to reflect the secondary content of the protein [22]. CD measurements have been widely used to follow the equilibrium between helical structures and unordered conformations [23]. Polypeptide conformations that determine protein secondary structures give rise to circular dichroism spectra [24]. Measuring the CD spectra of L2 lipase allowed rapid determination of the secondary structure content of L2 lipase. The purified L2 lipase was first diluted to a concentration of $0.2 \mathrm{mg} / \mathrm{ml}$ before subjected to CD and its far UV spectra 190-240 nm were obtained (Figure 9). L2 lipase was determined structurally to be $38.6 \%$ $\alpha$-helix, $2.2 \%$ ß-sheet, $23.6 \%$ B-turn and $35.6 \%$ random coil. 
Figure 9. Molecular ellipticity value measurement for L2 mature lipase. Secondary structure prediction of L2 lipase was done by the CD spectra at $220 \mathrm{~nm}$.

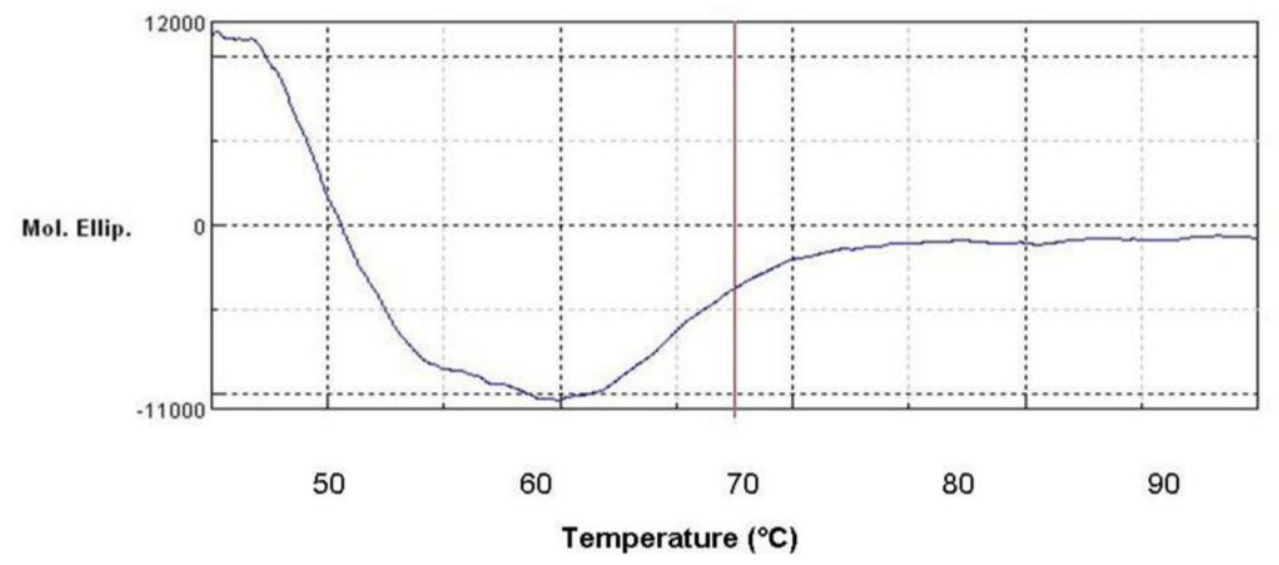

\section{Experimental Section}

\subsection{Strains, Plasmids and Growth Conditions}

Bacillus sp. strain L2 used as the wild-type strain was isolated from a hot spring in Perak, Malaysia [25]. This strain was grown at $70{ }^{\circ} \mathrm{C}$ in trypticase soy broth (TSB) and also on a nutrient agar plate for 28 hours. E. coli M15[pREP4] (Qiagen, Valencia, CA, USA) was used as a heterologous cloning and expression host for recombinant studies and was grown in LB supplemented with $25 \mu \mathrm{g} / \mathrm{mL}$ (w/v) kanamycin. Plasmid pQE-30 UA (Qiagen, Valencia, CA, USA) was used for cloning and also as an expression vector.

\subsection{Nucleic Acid Manipulation}

Genomic DNA of Bacillus sp. strain L2 was extracted using the DNeasy tissue kit (Qiagen, Valencia, CA, USA) according to the manufacturer's manual. Plasmid DNA was isolated with the Mini Plasmid Kit (Qiagen, Valencia, CA, USA). Extraction of both genomic and plasmid DNA from agarose was performed with the Gel Extraction Kit (Qiagen, Valencia, CA, USA) as specified by manufacturer. Competent E. coli M15[pREP4] cells were prepared using the protocol from (Qiagen, Valencia, CA, USA).

\section{3. $16 S$ rDNA Gene Sequence Amplification}

16S rDNA gene sequence was amplified via polymerase Chain Reaction (PCR) using two degenerate universal primers: 16s Forward: 5'-CCG AAT TCG TCG ACA ACA GAG TTT GAT CCT GGC TCA G-3'; and 16s Reverse: 5'-CCC GGG ATC CAA GCT TAC GGC TAC CTT GTT ACG ACT T-3'. The expected PCR product is $1500 \mathrm{bp}$. Amplification process was carried out in $100 \mu \mathrm{L}$ of reaction mixture containing $1.5 \mathrm{mM} \mathrm{MgCL}_{2}, 1 \times$ PCR buffer, $0.2 \mathrm{mM}$ dNTP mix, $2 \mathrm{U}$ of Taq DNA Polymerase, 20 pmol of each forward and reverse primers and genomic DNA (50-100 ng). The gene was amplified with a thermocycler (Gene Amp PCR system 2400, Perkin Elmer, Foster, CA, USA). The conditions for the PCR amplification were as follows: pre-denaturation at $94{ }^{\circ} \mathrm{C}$ for 4 min, 
denaturation at $94{ }^{\circ} \mathrm{C}$ for $1 \mathrm{~min}$, annealing at $58{ }^{\circ} \mathrm{C}$ for $2 \mathrm{~min}$, extension at $72{ }^{\circ} \mathrm{C}$ for $1 \mathrm{~min}$, final extension at $72{ }^{\circ} \mathrm{C}$ for $7 \mathrm{~min}$ and preservation at $4{ }^{\circ} \mathrm{C}$.

The amplified products were detected by electrophoresing $10 \mu \mathrm{L}$ of PCR product through $1 \%$ agarose gel at $70 \mathrm{~mA}$ for $30 \mathrm{~min}$ and then subjected to staining with ethidium bromide $(1 \mu \mathrm{g} / \mu \mathrm{L})$ for $15 \mathrm{~min}$ and later ligated into TA cloning vector (Invitrogen, Carlsbad, CA, USA, ) according to manufacturer's instructions. After transformation into E. coli, the plasmids were extracted and sent for sequencing. A DNA homology search was performed with GenBank database [26].

\subsection{Phylogenetic Tree Analysis}

A phylogenetic tree based on comparison of 16S rDNA sequence of this strain and other strains of Bacillus species was constructed. All sequences were aligned with CLUSTAL W 1.75 [27]. Phylogeny tree was constructed in Biology Workbench 2.0 [28]. 16S rDNA sequences of other Bacilli were obtained from GenBank database [26].

\subsection{Isolation of the Lipase Gene}

Bacillus sp. L2 genomic DNA (diluted 1:10, approximately $10 \mathrm{ng}$ ) was used as a template for the PCR amplification of lipase gene fragments, using the degenerate consensus primers listed below with the possible combinations.

Lip F2: 5'-TAG AGA ACG GAA GCC AAG AAG A-3'

Lip R2: 5'-GAG CCG TTC AAA ATA ATG GTC G-3'

P1R1: 5'-TTA AGG CTG CAA GCT CGC CAACTG-3'

F: 5'-CAG AAA ACC CGA CAA TTG CCG-3'

Mature: 5'-GCA TCC CTA CGC GCC CAT GAT-3'

PCR was carried out in $100 \mu \mathrm{L}$ of mixture containing $1.5 \mathrm{mM} \mathrm{MgCl}_{2}, 1 \times$ PCR buffer, $0.2 \mathrm{mM}$ dNTP mix, 2.5 U Taq DNA Polymerase, 20-30 pmol each reverse and forward primers and DNA template (50-100 ng). The reaction mixture was amplified in a thermocycler (GeneAmp PCR System 2400, Perkin Elmer, CA, USA). The conditions for the PCR amplification were as follows: pre-denaturation at $95{ }^{\circ} \mathrm{C}$ for $4 \mathrm{~min}$, denaturation at $95{ }^{\circ} \mathrm{C}$ for $1 \mathrm{~min}$, annealing at $55{ }^{\circ} \mathrm{C}$ for 2 min for primers Lip F2/Lip R2 and Lip F2/PIRI and $58{ }^{\circ} \mathrm{C}$ for 2 min for primers F/Lip R2 and Mature/P1R1, extension at $95{ }^{\circ} \mathrm{C}$ for $1 \mathrm{~min}$, final extension at $95{ }^{\circ} \mathrm{C}$ for $7 \mathrm{~min}$ and preservation at $4{ }^{\circ} \mathrm{C}$.

\subsection{Cloning of PCR Product}

The purified DNA of the amplified mature lipase gene was directly cloned with pQE-30 UA expression vector (Qiagen, Valencia, CA, USA) according to the manufacturer's instructions. The transformation medium was plated onto separated LB-trybutyrin plates $(100 \mu \mathrm{g} / \mathrm{mL}$ ampicillin, $25 \mu \mathrm{g} / \mathrm{mL}$ kanamycin) and incubated at $37{ }^{\circ} \mathrm{C}$ overnight. Colonies that produced clearing zones on tributyrin-ampicillin-kanamycin LB agar were isolated and restreaked on triolein-ampicillin-kanamycin agar. Formation of blue zones around the colonies indicated lipase activity. 


\subsection{Sequencing of the Thermostable Lipase Gene}

The purified recombinant plasmid was sent for automated sequencing (Institute of Bioscience, UPM). Samples were sequenced using an ABI PRISM 377 Genetic Analyzer (Perkin-Elmer). Analysis of the sequence and database similarity search were done using BLAST from National Center for Biotechnology (NCBI) [29], ExPASy Molecular Biology server [6] and Biology Workbench [28].

\subsection{Expression of the L2 Lipase Gene}

The E. coli strain harboring recombinant plasmids was grown for 3 hours in $500 \mathrm{~mL}$ bottles containing $100 \mathrm{~mL}$ of $\mathrm{LB}$ medium supplemented with $100 \mu \mathrm{g} / \mathrm{mL}$ ampicillin and $25 \mu \mathrm{g} / \mathrm{mL}$ kanamycin on a rotary shaker $(200 \mathrm{rpm})$ at $37{ }^{\circ} \mathrm{C}$. The culture was induced with $1 \mathrm{mM}$ of isopropyl- $\beta$-D-thiogalactopyranoside (IPTG) at $\mathrm{OD}_{600 \mathrm{~nm}} \sim 0.5$ for 3 hours. Cultures $(10 \mathrm{~mL})$ were harvested by centrifugation and resuspended with $10 \mathrm{~mL}$ of $50 \mathrm{mM}$ potassium phosphate buffer (pH 7.0) before sonication (Branson 250 sonifier: output 2, duty cycle 30 and min 2) and cleared by centrifugation (12,000 rpm, $20 \mathrm{~min})$. The clear crude lysate was used in the lipase assay.

\subsection{Assay of Lipase Activity}

The lipase activity was assayed colorimetrically by a method developed by Kwon and Rhee [30]. Culture filtrate $(1 \mathrm{~mL})$ was shaken with $2.5 \mathrm{~mL}$ of olive oil $(70 \%$ oleate residues) emulsion $(1: 1 \mathrm{v} / \mathrm{v})$ and $20 \mu \mathrm{L}$ of $0.02 \mathrm{M} \mathrm{CaCl}_{2}$ in a water bath shaker at an agitation rate of $200 \mathrm{rpm}$. The emulsion was prepared by mixing together an equal volume of olive oil (Bertoli, Italy) and $50 \mathrm{mM}$ phosphate buffer with a magnetic stirrer for 10 minutes. The reaction mixture was shaken for $30 \mathrm{~min}$ at $70{ }^{\circ} \mathrm{C}$. The enzyme reaction in the emulsion system was stopped by adding $6 \mathrm{~N}$ HCL $(1 \mathrm{~mL})$ and isooctane $(5 \mathrm{~mL})$, followed by mixing using a vortex mixer for $30 \mathrm{~s}$. The upper isooctane layer $(4 \mathrm{~mL})$ containing the fatty acid was transferred to a test tube for analysis. Copper reagent $(1 \mathrm{~mL})$ was added and again mixed with a vortex mixer for $30 \mathrm{~s}$. The absorbance of the upper layer was read at $716 \mathrm{~nm}$. Lipase activity was measured by measuring the amount of free fatty acid released from the standard curves of free fatty acids. One unit of lipase activity was defined as the amount of enzyme releasing $1 \mu$ mole of fatty acid per minute.

\subsection{Effect of Different Concentrations of Inducer (IPTG) on Crude Lipase Expression}

The effects of using different concentrations of inducer (IPTG) was assessed by inducing the E.coli M15[pREP4] cells that had recombinant plasmids with different concentrations of IPTG: $0 \mathrm{mM}$, $0.25 \mathrm{mM}, 0.5 \mathrm{mM}, 0.75 \mathrm{mM}$ and $1.0 \mathrm{mM}$ at $\mathrm{OD}_{600 \mathrm{~nm}} \sim 0.5$ for $3 \mathrm{~h}$ of induction time at $37{ }^{\circ} \mathrm{C}$. The best IPTG concentration was used for further studies.

\subsection{Time-Course Analysis of Crude Lipase Expression}

Time-course studies were performed by collecting the cell pellet at different post-induction times: 0 , $3,6,9,12,18$ and $36 \mathrm{~h}$ at $37{ }^{\circ} \mathrm{C}$. The studies were also repeated with a shorter time frame 
(0 to $6 \mathrm{~h}$ ). In this study, $1 \mathrm{mM}$ of IPTG was used as an inducer. The best post-induction time was chosen for further studies.

\subsection{Purification of Recombinant Lipase L2}

The cell pellet from a $200 \mathrm{~mL}$ culture was suspended in $20 \mathrm{~mL}$ of binding buffer $(20 \mathrm{mM}$ sodium phosphate, $500 \mathrm{mM} \mathrm{NaCl}, 20 \mathrm{mM}$ imidazole) before sonication (Branson 250 sonifier: output 2, duty cycle 30 and $\mathrm{min} 2$ ) and cleared by centrifugation (10,000 rpm, $30 \mathrm{~min})$. The clear lysate was collected and used as the crude enzyme in purification using a Ni-Sepharose affinity chromatography column. The crude L2 lipase solution was purified to homogeneity by a one-step purification protocol using immobilized metal affinity chromatography (IMAC). The purification procedure was performed using an AKTA purifier system (Amersham Bioscience, USA) according to the manufacturer's instructions. Ni-Sepharose 6 Fast Flow (5 mL) was used as the matrix in an XK 16/20 (GE Healthcare, Salt Lake City, UT, USA) column. Equilibration was performed using binding buffer ( $20 \mathrm{mM}$ sodium phosphate, $500 \mathrm{mM} \mathrm{NaCl}, 20 \mathrm{mM}$ imidazole).

An aliquot of $20 \mathrm{~mL}$ of filtered crude recombinant L2 lipase was loaded in the equilibrated column at a flow rate of $0.5 \mathrm{~mL} / \mathrm{min}$. The column was washed with five column volumes of binding buffer. The recombinant L2 lipase was eluted with $10 \mathrm{CV}$ of elution buffer (20 mM sodium phosphate, $500 \mathrm{mM} \mathrm{NaCl}, 500 \mathrm{mM}$ imidazole, $\mathrm{pH}$ 7.4) using a linear gradient of imidazole ranging from 20 to $500 \mathrm{mM}$. The eluted fractions were subjected to SDS-PAGE analysis, lipase assay and Bradford assay.

\subsection{SDS-PAGE Analysis of Bacterial Protein}

SDS-PAGE was carried out on $12 \%$ running gel by using the method of Laemmli (1970) [31]. A broad range of prestained protein standard (MBI Fermentas; St. Leon-Rot, Germany) was used as a molecular mass marker. After electrophoresis, gels were stained with Coomasie Brilliant Blue R-250 (BioRad, Hercules, CA, USA).

\subsection{Effect of $p H$ on Lipase Activity and Stability}

Enzymatic activity was measured at various $\mathrm{pH}$ values $(\mathrm{pH} 4-12)$ for $30 \mathrm{~min}$ at $70{ }^{\circ} \mathrm{C}$. The substrate (olive oil) was prepared in $50 \mathrm{mM}$ of various buffers; acetate buffer ( $\mathrm{pH} 4.0-6.0$ ), potassium phosphate buffer ( $\mathrm{pH}$ 6.0-8.0), Tris- $\mathrm{HCl}$ buffer ( $\mathrm{pH}$ 8.0-9.0), glycine- $\mathrm{NaOH}$ buffer ( $\mathrm{pH}$ 9.0-11.0), and $\mathrm{Na}_{2} \mathrm{HPO}_{3} / \mathrm{NaOH}$ buffer ( $\mathrm{pH}$ 11.0-12.0). The effect of $\mathrm{pH}$ on lipase stability was determined by incubating aliquots of L2 lipase in buffers of different $\mathrm{pH}$ values for $30 \mathrm{~min}$ at $70{ }^{\circ} \mathrm{C}$. Residual activity was assayed using the Kwon and Rhee method.

\subsection{Effect of Temperature on Lipase Activity and Stability}

The optimum temperature for lipase activity was determined over the range of $40-85{ }^{\circ} \mathrm{C}$. The substrate was equilibrated at the required temperature for $5 \mathrm{~min}$ before the addition of enzyme. The effect of temperature on lipase stability was determined by incubating aliquots of the purified L2 lipase in Glycine- $\mathrm{NaOH}$ pH 9.0 at $60{ }^{\circ} \mathrm{C}$ to $80^{\circ} \mathrm{C}$ in intervals of $5{ }^{\circ} \mathrm{C}$. The residual activity was measured at the optimum temperature $\left(70^{\circ} \mathrm{C}\right)$. 


\subsection{Denatured Protein Analysis}

The variable temperature measurement of L2 lipase was performed by employing $10 \mathrm{~mm}$ cell after checking the circular dichroism (CD) value at $220 \mathrm{~nm}$. The warm-up period was 50 to $95{ }^{\circ} \mathrm{C}$, and the step was 1 degree per minute. The wavelength was set to $220 \mathrm{~nm}$. The concentration was $1 \mathrm{mg} / \mathrm{mL}$ and top of the cell was completely closed using a cap. Data pitch, bandwidth, response, scanning speed, and accumulation were set to be 0.1 degree, $1 \mathrm{~nm}, 8$ seconds, 1 degree per minute, 8 times, respectively.

\subsection{Effect of Metal Ions on Lipase Activity}

The activity of the purified L2 lipase was studied following incubation with $1 \mathrm{mM}$ and $10 \mathrm{mM}$ concentrations of various metal chlorides $\left(\mathrm{Na}^{+}, \mathrm{K}^{+}, \mathrm{Mg}^{2+}, \mathrm{Ca}^{2+}, \mathrm{Fe}^{2+}, \mathrm{Mn}^{2+}, \mathrm{Zn}^{2+}\right.$, and $\left.\mathrm{Cu}^{2+}\right)$ in $50 \mathrm{mM}$ Glycine- $\mathrm{NaOH}$ buffer $\mathrm{pH} 9.0$ at $65{ }^{\circ} \mathrm{C}$ for $30 \mathrm{~min}$. The residual activity was determined at $70{ }^{\circ} \mathrm{C}$ using olive oil emulsion and expressed as a percentage of activity without the metal chlorides.

\subsection{Influence of Various Effectors on Lipase Activity}

The influence of various effectors on purified L2 lipase activity was determined by incubating the purified L2 lipase at $65^{\circ} \mathrm{C}$ for $30 \mathrm{~min}$ in $50 \mathrm{mM}$ Glycine- $\mathrm{NaOH}$ buffer $\mathrm{pH} 9.0$ with dithiothreitol (DTT), 2-mercaptoethanol, phenylmethylsulfonyl fluoride (PMSF), ethylene diaminetetra acetic acid (EDTA), and pepstatin A at different concentrations (1 $\mathrm{mM}$ and $5 \mathrm{mM})$ except for pepstatin $(1 \mathrm{mM})$. The residual activity was measured at $70{ }^{\circ} \mathrm{C}$ and expressed as percentage of activity without inhibitors.

\subsection{Circular Dichroism (CD) Spectral Analysis of L2 Lipase}

Purified L2 lipase in sodium phosphate buffer ( $\mathrm{pH}$ 8.0) was analyzed with spectropolarimeter J-810 (Jasco, Tokyo, Japan) for CD spectral analysis. The warm-up periods of 50 to $95{ }^{\circ} \mathrm{C}$ and wavelength scan of 180 to $250 \mathrm{~nm}$ were taken into consideration.

\section{Conclusions}

In this study, we reported the identification of a newly isolated thermostable lipase producer, Bacillus sp. L2, the PCR cloning, sequencing and over-expression of a functional form of thermostable lipase L2, as well as purification and characterization studies. The full sequence of the L2 lipase gene was analyzed. A high-level expression was also successfully achieved by using the pQE-30/E. coli M15[pREP4] expression system. This system worked efficiently and overexpression of recombinant L2 was successfully carried out with a 178-fold higher activity compared to crude native L2 lipase. So far, no other lipases have been reported to successfully use this expression system. Therefore, we conclude that L2 lipase is the first lipase for which this system has been successfully used.

The recombinant L2 lipase was easily recovered via a single-step affinity chromatography purification method with high purity and high yield purification, leading to a low-cost method for preparation of this enzyme. The characterization of this enzyme resulted in some interesting findings, such as its thermostability profile and its wide range of $\mathrm{pH}$ stability, indicating that L2 lipase has significant potential for commercialization as a biocatalyst for industrial purposes, specifically, in 
detergent industries and food industries that use esterification process at high temperature. Therefore, in comparison with other commercially available enzymes, the use of L2 lipase for industrial applications seems promising as it is more stable at higher temperatures.

\section{Acknowledgement}

This research was supported by the Ministry of Science, Technology, and Innovation, Malaysia (09-02-04-0336-EA001).

\section{References}

1. Arpigny, J.L.; Jaeger, K.-E. Bacterial lipolytic enzymes: Classification and properties. Biochem. J. 1999, 343, 177-183.

2. Jaeger, K.; Eggert, T. Lipases for biotechnology. Curr. Opin. Biotechnol. 2002, 13, 390-397.

3. Sharma, R.; Chisti, Y.; Banerjee, U.C. Production, purification, characterization, and applications of lipases. Biotech. Adv. 2002, 19, 627-662.

4. Coolbear, T.; Daniel R.M.; Morgan H.W. The enzymes from extreme thermophiles: Bacterial sources, thermostabilities and industrial relevance. Adv. Biochem. Eng. Biotechnol. 1992, 45, 57-98.

5. Nazina, T.N.; Tourova, T.P.; Poltaraus, A.B.; Novikova, E.V.; Grigoryan, A.A.; Ivanova, A.E.; Lysenko, A.M.; Petrunyaka, V.V.; Osipov, G.A.; Belyaev, S.S.; Ivanov, M.V. Taxonomic study of aerobic thermophilic bacilli: Descriptions of Geobacillus subterraneus gen. nov., sp. nov. and Geobacillus uzenensis sp. nov. from petroleum reservoirs and transfer of Bacillus stearothermophilus, Bacillus thermocatenulatus, Bacillus thermoleovorans, Bacillus kaustophilus, Bacillus thermoglucosidasius and Bacillus thermodenitrificans to Geobacillus as the new combinations G. stearothermophilus, G. thermocatenulatus, G. thermoleovorans, G. kaustophilus, G. thermoglucosidasius and G. thermodenitrificans. Int. J. Syst. Evol. Micr. 2001, 51, 433-446.

6. ExPASy Tools. ExPASy Proteomics Server. Swiss Institute of Bioinformatics: Lausanne, Switzerland, 2011. Available online: http://www.expasy.org/tool (accessed on 14 April 2011).

7. SignalP Server. SignalP V2.0.b2. Center for Biological Sequence Analysis (CBS): Lyngby, Denmark, 2011. Available online: http://www.cbs.dtu.dk/services/SignalP-2.0/ (accessed on 14 April 2011).

8. Bornscheuer, U.T.; Bessler, C.; Srinivas, R.; Krishna, S.H. Optimizing lipase and related enzymes for efficient application. Trends Biotech. 2002, 20, 433-437.

9. Hamid, A.S. Cloning and Expression of Alkaline Protease Gene from Bacillus Stearothermophilus Strain F1. MS Thesis, Universiti Putra Malaysia: Serdang, Malaysia, 2000.

10. Sinchaikul, S.; Sookkheo, B.; Phutrakul, S.; Pan, F.M.; Chen, S.T. Optimization of a thermostable lipase from Bacillus stearothermophilus P1: Overexpression, purification, and characterization. Protein Expr. Purif. 2001, 22, 388-398.

11. Leow, T.C.; Rahman, R.N.Z.R.A.; Basri, M.; Salleh, A.B. High level expression of thermostable lipase from Geobacillus sp. Strain T1. Biosci. Biotech. Biochem. 2004, 68, 96-103. 
12. Nthangeni, M.B.; Patterton, H.G.; van Tonder, A.; Vergeer, W.P. Over-expression and properties of a purified recombinant Bacillus licheniformis lipase: A comparative report on Bacillus lipases. Enzyme Microbial. Technol. 2001, 28, 705-712.

13. Mosbah, H.; Sayari, A.; Bezzine, S.; Gargouri, Y. Expression, purification, and characterization of His-tagged Staphylococcus xylosus lipase wild-type and its mutant Asp 290 Ala. Protein Expr. Purif. 2006, 47, 516-523.

14. Dharmsthiti, S.; Luchai, S. Production, purification and characterization of thermophilic lipase from Bacillus sp. THL027. FEMS Microbiol. Lett. 1999, 179, 241-246.

15. Jaeger K.E.; Ransac, S.; Dijkstra, B.W.; Clson, C.; Heuvel, M.V.; Misset, O. Bacterial lipases. FEMS Microbiol. Rev. 1994, 15, 29-63.

16. Nawani, N.; Dosanjh, N.S.; Kaur, J. A novel thermostable lipase from a thermophilic Bacillus sp.: Characterization and esterification studies. Biotechnol. Lett. 1998, 20, 997-1000.

17. Sharma, R.; Chisti, Y.; Banerjee, U.C. Production, purification, characterization, and applications of lipases. Biotech. Adv. 2002, 19, 627-662.

18. Wang, Y.; Srivastava, K.C.; Shen, G.J.; Wang, H.Y. Thermostable alkaline lipase from a newly isolated themrophilic Bacillus strain, A30-1 (ATCC 53841). J. Ferment. Bioengineer. 1995, 79, 433-438.

19. Lee, D.W.; Kim, H.W.; Lee, K.W.; Kim, B.C.; Choe, E.A.; Lee, H.S.; Kim, D.S.; Pyun, Y.R. Purification and characterization of two distinct thermostable lipases from the gram-posistive thermophilic bacterium Bacillus thermoleovorans ID-1. Enzyme Microbial. Technol. 2001, 29, 363-371.

20. Kim, H.-K.; Park, S.-Y.; Lee, J.-K.; Oh, T.-K. Gene cloning and characterisation of thermostable lipase from Bacillus stearothermophilus. Biosci. Biotech. Biochem. 1998, 62, 66-71.

21. Gary, C.J. Stabilization of enzymes with soluble additives. In Thermostability of Enzyme; Gupta, M.N., Ed.; Narosa: New Delhi, India, 1995; pp. 124-143.

22. Sreerama, N.; Venyaminov, S.Y.; Woody, R.W. Estimation of protein secondary structure from circular dichroism spectra: Inclusion of denatured proteins with native proteins in the analysis. Anal. Biochem. 2000, 287, 243-251.

23. Schröder, O.; Tippner, D.; Wagner, R. Towards the three-dimensional structure of the Escherichia coli DNA-binding protein H-NS: A CD and fluorescence study. Biochem. Biop. Res. Co. 2001, 282, 219-227.

24. Yang, J.T.; Wu, C.S.C.; Martinez, H.M. Calculation of protein conformation from circular dichroism. Meth. Enzymol. 1986, 130, 208-269.

25. Shariff, F.M.; Leow, T.C.; Mukred, A.D.; Salleh, A.B.; Basri, M.; Rahman, R.N.Z.R.A. Production of L2 lipase by Bacillus sp. strain L2: Nutritional and physical factors. J. Basic Microbiol. 2007, 47, 406-412.

26. National Center for Biotechnology Information (NCBI) Home Page, Bethesda, MD, USA, 2011. Available online: http://www.nlm.ncbi.nih.gov (accessed on 14 April 2011).

27. Thompson, J.D.; Higgins, D.G.; Gibson, T.J. CLUSTAL W: Improving the sensitivity of progressive multiple sequence alignment through sequence weighting, position-specific gap penalties and weight matrix choice. Nucl. Acids Res. 1994, 22, 4673-4680. 
28. SDSC Biology Workbench. San Diego Supercomputer Center: San Diego, USA, 2011. Available online: http://workbench.sdsc.edu/ (accessed on 14 April 2011).

29. NCBI/BLAST-Basic Logic Alignment Search Tool. National Center for Biotechnology Information (NCBI): Bethesda, MD, USA, 2011. Available online: http://blast.ncbi.nlm.nih.gov/Blast.cgi (accessed on 14 April 2011).

30. Kwon, D.K.; Rhee, J.S. A simple and rapid colorimetric method for determination of free fatty acids for lipase assay. J. Am. Oil. Chem. Soc. 1986, 63, 89-92.

31. Laemmli, U.K. Cleavage of structural proteins during the assembly of the head of bacteriophage T4. Nature 1970, 227, 380-685.

(C) 2011 by the authors; licensee MDPI, Basel, Switzerland. This article is an open access article distributed under the terms and conditions of the Creative Commons Attribution license (http://creativecommons.org/licenses/by/3.0/). 